\title{
The Guangdong-Hong Kong nexus in grassroots collective actions amid Sino-Anglo interface, 1841 to 1927
}

\author{
Kent Wan \\ School of History, Nanjing University, Nanjing, China
}

\begin{abstract}
Purpose - This paper provides an analytical account detailing the historical linkages between Chinese on both sides of the Sino-Hong Kong border from 1841 onwards and examining important incidents of collective actions in the colony and Canton.

Design/methodology/approach - Using annual reports published by the colonial administration in Hong Kong, especially those focusing on years that witnessed major incidents of anti-colonial agitations, this paper analyzes how British policymakers were confronted by collective actions mounted by Chinese in Canton and Hong Kong. Building on the works of prominent historians and utilizing the theoretical frameworks of analysts such as Charles Tilly (1978), the author examines if a Cantonese regional solidarity served as the foundation for popular movements, which in turn consolidated a rising Chinese nationalism when Canton and Hong Kong were the focal points of mass actions against imperialism.

Findings - Hong Kong Chinese workers were vanguards of the modern Chinese revolutions that transformed not just their homeland, but their lives, allegiances, and aspirations as Chinese in a domain under foreign jurisdiction on Chinese soil, as their actions were emulated by their compatriots outside of South China, thus starting a chain reaction that culminated in the establishment of the Nanjing regime.

Originality/value - This paper reveals that popular movements of Hong Kong Chinese possessed national and international importance, especially when they were supported by their Cantonese compatriots and the two leading Chinese political parties, the Kuomintang (KMT) and the Chinese Communist Party (CCP).
\end{abstract}

Keywords Chinese nationalism, Collective actions, Cantonese solidarity, Chinese history, Hong Kong history, British colonialism

Paper type Research paper

\section{Introduction}

While they were often underappreciated and largely ignored in academic scholarship, ordinary men and women on the frontline of Hong Kong's economic and political transformations were of immense strategic significance to both their colonizers and mainland regimes that attempted to combat perceived imperialist encroachments on Chinese sovereignty. This paper will examine anti-colonial collective actions against the British mounted by the Hong Kong Chinese grassroots from the mid- $19^{\text {th }}$ century to the 1920 s, and how social, cultural, economic, and political ties that united Guangdong and Hong Kong provided those who were resisting

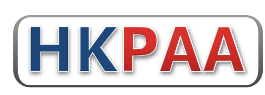

(c) Kent Wan. Published in Public Administration and Policy. Published by Emerald Publishing Limited. This article is published under the Creative Commons Attribution (CC BY 4.0) license. Anyone may reproduce, distribute, translate and create derivative works of this article (for both commercial and noncommercial purposes), subject to full attribution to the original publication and authors. The full terms of this license may be seen at http://creativecommons.org/licences/by/4.0/legalcode

The author would like to express his profound gratitude to Professor Ming K. Chan, whose generosity, guidance, and friendship made the publication of this paper possible. This paper is based on the inputs and opinions of Professor Chan, and he intended to publish it jointly with the author. Professor Chan unexpectedly passed away in 2018, thus leaving the tasks of finalizing and publishing his final academic paper to the author.

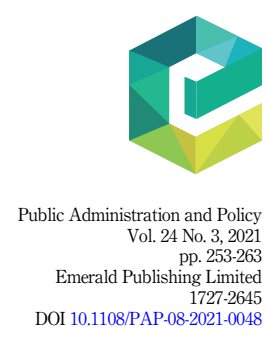


PAP

24,3 colonialism in Hong Kong with allies in Canton in their efforts to undermine British imperialism in South China.

In terms of its strategic locale, colonial Hong Kong coming under British rule had much to do with its beachhead, gateway, and platform hub functions in repeated western attempts to penetrate and even dominate the China trade and the mainland Chinese market (Tsang, 2004, p. 17). As such, linkages between British Hong Kong and the mainland definitely had been of paramount importance in Hong Kong's growth, developments, and historical transformations from a collection of fishing villages on a barren rock to one of the most significant shipping and trade centers of the Far East (Tsang, 2004, p. 57). This paper chronicles and analyzes a series of large-scale popular actions that were much more than labour strikes and the impact of which reverberated beyond the border of Hong Kong. While incidents of perceived injustice that occurred in the colony no doubt constituted a motivating factor for collective actions, the workers of Hong Kong were highly attuned to political events occurring outside of the colony, meaning that they were often enraged by actions of foreign powers that were interpreted as damaging to the social, economic, and political interests of their compatriots in other parts of the mainland. Given that Guangdong was not only the native province of the majority of the colony's Chinese workers, but was also a site of confrontations between foreign powers and political organizations with aspirations to becoming the ruling regime of China, it was only natural for the KMT, when its political base was in Canton, to offer political and financial support to Hong Kong Chinese workers when they were mobilizing against the British. Collective actions in Hong Kong assumed national and international importance when their participants were supported by a political organ determined to become the ruling party of China, one that offered them shelter in the city of Canton, the capital of a province containing men and women who spoke the same dialect as that of the colony's workers. Using primary sources such as reports published by the British Colonial Office and synthesizing the works of leading historians and social scientists, this paper asserts that popular movements participated by the Chinese workers of Hong Kong severely undermined British authority and prestige, thereby creating examples for their compatriots in other parts of China to emulate and cementing a Chinese nationalism that culminated in the establishment of the Nanjing regime in 1927.

\section{Analytical framework}

Given the richness of southern Chinese culture that was treasured by Chinese who saw Guangdong as their ancestral province, analysts could use Anthony D. Smith's argument (1998, p. 193), that unity within a community was established upon shared symbols, values, myths and traditions of its members who were then able to pass on their cherished cultural heritage to successive generations, to better understand how a sense of regional solidarity emerged in Guangdong. Indeed, according to Helen Siu, men and women residing in Guangdong spoke "a distinctive dialect (yue)" and had since the Song dynasty, cultivated "myths and regional historiographies, compiled genealogies, and built ornate ancestral halls with literati pretension", all in an effort to claim a status of equality with their northern compatriots (Siu, 2016, p. 31, p. 37). There existed a "collective cultural identity" among Chinese in Guangdong that was centuries in the making, so much so that adherents of this cultural identity were willing to mobilize to defend their ancestral home when it was under threat (Smith, 1993, p. 49).

Since Guangdong's capital, Canton, was an economic interface between China and the world, thereby making its inhabitants much more exposed to foreign incursions into Chinese territories than their compatriots in other regions of China, it is not surprising that during the period of Qing Empire's decline, Chinese of the city often found themselves at the frontline of anti-foreign agitations (Siu, 2016, pp. 34-35). According to Frederic Wakeman, the appearance 
of powerful external enemies such as the British motivated the Cantonese to unite against outside threats, efforts that were participated by their compatriots in British Hong Kong. Of course, cultural unity could not overcome conflicting class and economic interests, and more often than not, local and class rivalries would quickly reemerge, thereby dooming the prospect of a regional solidarity becoming a sustained political force during the late-Qing period. The existence of a shared cultural identity notwithstanding, divergent economic interests between different classes limited anti-foreign resistance to sporadic outbursts that dissipated almost as suddenly as they emerged (Wakeman, 1966, p. 115, p. 167).

During the 1920s, however, revolutionary organizations with aspirations to govern all of China would come to see as powerful political instruments the Chinese workers of Hong Kong, as they were highly adept at inflicting substantial damages to British interests in Hong Kong and China (Chan, 1975, p. 313; Jacobs, 1981, p. 140). The KMT's "Canton Decade" that started with its installation in Canton in 1917 and concluded with the establishment of the Nanjing regime was full of trials and tribulations, as it had to fight other militarists in the province and even stave off coup attempts by prominent merchants distrustful of the party, meaning that it was only able to successfully consolidate control over all of Guangdong through successive military campaigns in 1926. Nevertheless, using the provincial capital as a political base, the party did emerge as the political protector of Chinese workers in Hong Kong (Chan, 1996, p. 227; Chan, 1994, p. 37, p. 44). Reliance on Chinese workers as partisans of mass actions would only intensify after the formation of the KMT-CCP United Front, an alliance that lasted from 1924 to 1927 (Jacobs, 1981, p. 182). Regional solidarity of workers in Canton and Hong Kong therefore had to be harassed by political organizations able to offer workers in the Pearl River Delta political protection from not only retaliations by the imperial powers, but also their compatriots in higher socioeconomic positions who saw prolonged popular movements as detrimental to their class interests. To operationalize the analytical framework of Charles Tilly, the Canton government acted as a vital facilitator of collective actions in Hong Kong and the Pearl River Delta by nullifying the campaigns of repression organized by the colonial administration and its allies (Tilly, 1978, p. 100). "Collective actions" that came close to eradicating British presence in South China were made possible by the alignment of "interests" between the Chinese grassroots of Hong Kong and the Canton regime that realized they needed one another in the "in pursuit of common ends", as the former had to secure political protection to confront the British, while the KMT, and later the United Front, wanted to use workers as shock troops of its political and military campaigns to exterminate domestic and foreign opponents (Tilly, 1978, p. 52, pp. 54-55).

"[R]esourceful southerners," be they statesmen leading Canton or workers in the Pearl River Delta, were so proud of their Southern Chinese heritage that what worried the opponents of the KMT and the United Front was not that they would mount some kind of separatist efforts, but that its leaders and supporters, many of whom of Cantonese origin, would compete for national power by leading popular and military movements that drew support from Chinese in and around Guangdong (Chan, 1996, p. 230; Siu, 1996, p. 180; Siu, 2016, p. 36). The support given by the KMT and the United Front to Hong Kong Chinese workers that was so vital in their capacity to seriously challenge British imperialism was thereby not to establish a regional strong base in Guangdong, but to use the province, especially its capital city, Canton, as the point of commencement of anti-imperial efforts that would grant the party the popular legitimacy necessary to launch a political and military campaign to unify China under its rule.

\section{Historical context: the original sin of colonialism in South China}

Hong Kong's strategic value derived from its status as the major economic hub of the British Empire in the Far East, one that allowed its merchants to dominate the China trade and 
ensured transpacific shipping would past through the colony's ports (Des Voeux, 1889, p. 21). Yet, the reliance on the China market and global shipping networks rendered Hong Kong vulnerable to political instability emanating from China, on the one hand, and the global economy, on the other, a situation common to many port cities on the China coast. AngloChina geopolitical tensions even created conflicts between Chinese in Hong Kong and their colonial rulers, as the local population was predominately Chinese and non-locally born. Indeed, the majority of Hong Kong's Chinese were émigrées from mainland China, especially Guangdong. In a sense, Anglo-Sino dynamics as articulated in the relations between Hong Kong and Canton and interactions between the Chinese grassroots and British colonial rulers shaped the chronicle of Hong Kong before the First World War.

Major cases of East-West confrontations erupted in Hong Kong during the first century of British rule. Chinese workers in Hong Kong were at the frontline both to keep Hong Kong functioning and at times of political, social, economic conflicts, the defenders of their own collective class interests as well as Chinese interests - local, regional, national, and international. Local strikes, boycotts, and other forms of collective actions staged by the Chinese grassroots of Hong Kong, by logic, and as a matter of necessity, could hardly escape the characterizations of conflicts between labour and capital, of ethnic-sociocultural tensions between oriental and occidental, and of British capitalism and imperialism against Cantonese solidarity and Chinese nationalism. Thus, grassroots collective actions must be regarded as fissures in state-society disequilibrium of Hong Kong and as peculiar historical constructs of British interests colliding with Chinese aspirations and survival instincts, with cross-border implications.

The British takeover of Hong Kong Island in 1841 during the final phase of the First Opium War that was sanctioned by the 1842 Treaty of Nanjing was often labelled the start of China's century of humiliation under the unequal treaties, or the age of western imperialism in China (Morris, 1988, pp. 25-26). Colonial occupation of Hong Kong also witnessed the concurrent British attempt to enforce another Nanjing Treaty provision: the right of entry into the walled city of Canton (Wong, 1998, p. 139). This provoked fierce resistance against the British by the Canton officialdom and local residents for several years, who viewed Hong Kong's colonization under the British Crown as the original sin of British oppression in China (Nield, 2015, pp. 59-60; Munn, 2009, p. 46). As evident by the locals' enthusiastic enlistment in the militias of Canton to defend their city and the readiness of men and women in Canton to form "screaming mob" that terrified "foreign merchants and native officials alike", such was Cantonese contempt towards the British that Peking actually sided with the local population in refusing British entry into the city, and the Emperor even stated that "if [the British] enter the city, there will be harm but no profit", thereby handing the Cantonese society a stunning victory in 1849 (Wakeman, 1966, p. 77, p. 96, p. 103).

\section{Hong Kong, Canton, and cross-border collective actions}

For most of the $19^{\text {th }}$ century, Canton-Hong Kong relationship at the formal regime to regime level was often stressful and antagonistic, while at the popular level, the Chinese on both sides of the border enjoyed brotherhood solidarity (Tsai, 1993, p. 52). Most of the Chinese residing in Hong Kong were natives of Guangdong who never became British subjects (Tsang, 2004, p. 46). Based on, stemmed from, and rooted in blood ties, clan-lineages, linguistic commonality, shared social-cultural heritage, and parallel or overlapped economic interests, Hong Kong and Canton were much more than cousins - they were brothers, and even twins (Chan, 1975, pp. 101-103). To quote Anthony D. Smith, the Chinese grassroots of Hong Kong and Canton were bonded by "a myth of common ancestry, shared memories and cultural elements, a link with an historic territory or homeland and a measure of solidarity", thus cementing a sense of commonality that would endure long after Hong Kong's colonization by the British (Smith, 1993, p. 49). 
The Second Opium War (1856-1860) resulted in the Convention of Peking that ceded the Kowloon Peninsula to the British colonial domain of Hong Kong (Tsang, 1995, pp. 31-32). During this period of Sino-British military hostilities, Chinese workers in Hong Kong rallied to the patriotic calls of anti-British resistance issued by the officialdom and elites of Canton. Indeed, after Canton fell to the British and the French in December 1857, "foreigners. . .found it difficult to buy food or hire help" in the provincial capital and Hong Kong (Wakeman, 1966, p. 168). In 1858, some 30,000 plus Chinese workers in the colony simply walked off from their jobs and returned to their homes in the mainland (Tsai, 1993, p. 58, p. 171). Another particularly noteworthy scandal was the bread poisoning incident of 1857, in which a Chinese-owned bakery was suspected of poisoning the bread supplies for Caucasian households, including members of the British officialdom, that resulted in widespread food poisoning among leading British families (Carroll, 2007, p. 26). It was widely assumed by both local Chinese and European residing in the colony that this poisoned bread scandal was a Chinese revenge against the Anglo-French joint occupation of their beloved city of Canton (Wakeman, 1966, pp. 159-164). During the Sino-French War (1883-1885) over French imperialism in Indochina, Hong Kong Chinese shipyard workers' refusal to repair a damaged French warship in 1884 triggered a widespread wave of sympathy strikes and anti-Caucasian boycotts among Chinese workers, including restaurant workers, hotels and domestic servants, who refused to serve foreign soldiers and sailors (Tsai, 1993, pp. 126-129). The local Chinese workers' patriotic resistance in defiance of British colonial repression forced the damaged French warship to seek repair elsewhere, and this case of "offshore Chinese patriotism" left a deep impression in the mind of a young Cantonese student in a Hong Kong high school (Hong Kong Government Central School), whose later career personified Chinese nationalism and Cantonese solidarity. His name was Sun Yat-sen (Tsai, 1993, p. 142).

The above cases were "reactive collective action[s]" that were reactions to incidents of injustices and consisted of relative spontaneous outbursts that lacked sustained and organized leadership, meaning that even if there were occasional victories, due to the fact that the officialdom in Canton and Chinese elites in both the provincial capital and the colony often suspended their support when they became fearful that large-scale mass actions would escape their control, thereby causing disturbances that would threaten not only the British, but also the existing social order, the actions of the Hong Kong and Cantonese grassroots during this sunset period of Qing rule did not pose an existential threat to British imperialism in South China. (Tilly, 1978, pp. 145-146; Tsai, 1993, pp. 134-135). One fact is nevertheless clear: Chinese workers in colonial Hong Kong resorted to collective economic actions to defend Chinese national interests, especially if their ancestral province and beloved city of Canton was threatened by foreign aggressions. Hong Kong was, and would always remain, their workplace and domicile, but never their home. In the early decades of the $20^{\text {th }}$ century, many Hong Kong workers, especially mechanics and seamen, actively responded to the calls for revolutionary undertakings of a fellow Cantonese, Sun Yat-sen, and his political organs, the leadership of which was by and large Cantonese as well (Lau, 1990, pp. 126-127). The solidarity, partnership, and even feudalistic, traditional, sociocultural ties that emerged in Guangdong but were carried to the British colony by Chinese workers were ready-made, convenient, and extremely powerful channel for revolutionary mass actions the purposes of which were the preservation of their collective interests, the defense of their ancestral province, and if harassed by a political organization that saw itself as the prime representative of an anti-imperialist Chinese nationalism, the creation of a new China. As we shall see, many Chinese in Hong Kong and Canton did not have to choose between regional solidarity and Chinese nationalism, as they were convinced that their home province ought to be the cradle of the revolution to create a China that would be freed from imperialism.

In the early days of the new Republic, a noteworthy instance of Chinese grassroots boycott against British colonial regime-British business collusion broke out in the form of the
GuangdongHong Kong nexus

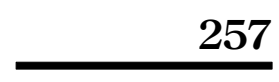


1912-1913 Tramway Boycott (Colonial Office, 1913, pp. 30-31; Munn, 2009, p. 377). This incident originated from a supposedly simple, if not innocent, economic cause. To prevent revenue losses due to the use of depreciated mainland-Cantonese copper coins, the Britishowned tramway on Hong Kong Island refused the payment of tram fare with Cantonese coins, which by then bore the Chinese Republic insignia and were minted in Canton since 1912 (Lau, 1990, pp. 107-114). This non-acceptance of Cantonese coins provoked widespread boycott of the tramway by local Chinese residents, which in turn led to the colonial authorities' imposition of a local neighborhood collective penalty for the boycott that was deemed illegal and counterproductive by Whitehall (Chan, 1994, pp. 29-31). The Legislative Council gave Governor Francis Henry May the authority to declare entire districts to be boycotting areas the residents of which had to pay fines that would be used to reimburse businesses targeted by the Boycott (Chan, 1994, p. 30). The draconian measures of the colonial government gradually weakened the will of the general public to continue to support the Boycott. By February 1913, the Boycott Prevention Ordinance was suspended as passenger traffic had by then returned to normal (Chan, 1994, p. 30). While the Boycott represented a series of relatively disorganized and leaderless protests that were eventually suppressed, the fact that there was such an immense backlash against a minor policy concerning the utilization of coins issued in Canton and bore the Republican insignia reveals that Chinese in Hong Kong were always ready to defend their native province and China, and the distinction between the two was not always clear given Canton's immense political and economic importance in the early days of the Republic (Chan, 1994, pp. 30-31).

\section{Landmark cases of collective actions in South China during the 1920s}

The outbreak of First World War saw Hong Kong on the side of the allies, while China remained neutral until 1916. The war triggered several economic processes. First, the War led to the destruction of East-West trade, a new reality that was severely damaging to Hong Kong, especially since the colony's prosperity was dependent upon its external trades (Colonial Office, 1919, p. 21; Colonial Office, 1920, p. 2). Second, global conflicts created challenges and risks in long distance shipping, affecting the lives of Cantonese seamen disembarking from Hong Kong. Third, on the global scale, the interruption of supply lines, which resulted in scarcity, disputation of production patterns, and a boom in new industrial investments by Japanese and Chinese interests in treaty ports, created demands for materials and skilled workers that propelled an inflationary spiral well into the interwar period (Chan, 1975, pp. 211-212, pp. 268-271; Chan, 1994, pp. 32-33, pp. 36-37). These objective economic preconditions represented the foundations for and root causes of major economic strikes that engulfed Hong Kong in 1920 and 1922; in both of these cases, workers were engaging in "proactive collective actions" to have their demands met by joining unions able to organize their members, meaning the capacity to impose discipline in preparation for the pursuit of collective objectives, and mobilize their assets, as there existed an imperative to marshal resources that would be used in the coming struggles (Tilly, 1978, p. 54, p. 147; Chan, 1994, p. 38, p. 40$)$.

The 1920 Mechanics' Strike, the climax of which saw some 30,000 Hong Kong mechanics walked off from their jobs and sought a safe refuge in Canton, represented the opening salvo of Hong Kong-Canton popular movements during the interwar years (Chan, 1994, pp. 37-38; Carroll, 2007, p. 97). The Canton sanctuary effect enhanced the strikers' bargaining power against the owner-management, while at the same time, removed the strikers from the repressive arms of the colonial regime and shielded them from retaliations by their employers (Chan, 1994, pp. 37-40). In the end, the strikers emerged victorious, and the colonial government tersely summed up the defeat of the management side during the 1920 Strike by stating that the participating "mechanics and skilled labour" obtained the "advances of 
wages by some 30 percent" (Colonial Office, 1922, p. 3). The same pattern was repeated two years later in the Seamen's Strike that, due to the ineptitude of the colonial administration, was turned into a political confrontation between British Hong Kong and the KMT-controlled Canton authorities. Governor Reginald Edward Stubbs, by resorting to high-handed measures and ill-justified legal means to ban the Seamen's Union and two coolies unions that participated in sympathy strikes, pushed itself into a legal jam (Chan, 1994, pp. 40-41).

Indeed, after banning the Seaman Union, the government then demanded it to change its name when it became clear that simple coercion was not going to end the Strike, as it was too embarrassing for the colonial regime to participate in negotiation with the very same entity that it had previously outlawed (Chan, 1975, p. 280). Worse still, unwarranted police conducts in removing the sign board of the Seamen's Union that bore the calligraphy of Sun Yat-sen "escalated and transformed this economic strike into a political confrontation between British colonial might and Chinese patriotic pride and working-class solidarity" (Chan, 1994, p. 41). Of course, the striking seamen and other strikers returned to Canton, where they were fed and housed by Canton labour organs, with the blessing of a sympathetic provincial and municipal leadership. The Canton sanctuary effect meant the prolongation of the Strike that paralyzed Hong Kong's global shipping and rendered everyday lives and overall economic activities to a total standstill (Chan, 1975, pp. 280-281). In the end, Stubbs had to rescind the ban on the unions, and the British policemen had to eat humble pie and restore the sign board of the Seamen's Union to its original place (Chan, 1994, p. 41). The shipping companies had to raise the seamen's salaries by 15 percent to 30 percent, a term stipulated by the strikers that finally ended the work stoppage (Chan, 1975, p. 281). Besides their Union's organization and mobilization skills, the seamen's victory was made possible by the full support of Canton state-society, which even helped enlisted financial aids from overseas Chinese communities around the globe (Chan, 1975, p. 277).

The victory of the Seamen's Union signaled beyond any doubt British imperial decline in Asia after the First World War and the emergence of the KMT as a force to be reckoned with in China, especially given its increased willingness to weaponize Chinese workers in and outside of Hong Kong. According to Tilly, before joining any opposition movements, participants of popular actions had to be convinced that the chance of having their interests advanced through victory had to outweigh the fear that they would be crushed by the regime in power (Tilly, 1978, p. 133). That the KMT leadership was willing to offer sanctuary to Chinese workers from Hong Kong in Guangdong's capital not only ensured the defeat of the colonial government in successive confrontations against the city's Chinese workers, but also signaled that the party would be a protector of Chinese who would stand up against the British, thereby encouraging further acts of defiance in the future.

The 16 months Canton-Hong Kong General Strike-Boycott from 1925 to 1926 had the unique distinction of being the best-known labour incident in Hong Kong and Guangdong history. Simply put, it was a series of collections actions for patriotic purpose, and a local response to the British massacre of Chinese workers and student protestors in Shanghai during the May $30^{\text {th }}$ Incident. The Strike-Boycott was a priority project of the KMT-CCP United Front that was "formed in January 1924 and committed to an anti-imperialist national revolution” (Chan, 1994, pp. 45-46). At its height, over a quarter million Hong Kong workers and their families left the colony and went to Canton, where the strike headquarter was located (Chan, 1994, p. 45). The Strike-Boycott was a retaliation against violent acts committed by the British and a series of proactive collective actions, as strikers from Hong Kong presented several demands, including the rights to freedom of speech, assembly and organization, democratic elections to the Legislative Council, housing reforms, reforms of labour legislations, and elimination of racial discrimination so that Chinese could reside anywhere in Hong Kong (Chan, 1994, p. 48). The Chinese workers of Hong Kong could not have imposed these demands on the British had they not been supported by their Cantonese 
PAP

24,3

260

compatriots and welcomed into Canton, which was controlled by a regime willing to offer sanctuary to opponents of British imperialism. Local and regional aspirations, and a desire to humble the British, could only be fulfilled by a regime based in Canton hellbent on exacting retributions from the imperialists. Anti-imperialism, Regional solidarity, and Chinese nationalism all compelled a large number of Chinese workers to support the Strike-Boycott.

In terms of organization, it was the CCP that was responsible for the day-to-day administration of the Strike-Boycott and the maintenance of internal order among its partisans, as the party took charge of functions such as reception, propaganda, recreation, general administration, and discipline (Chan, 1975, p. 315). Concerning mobilization, it was up to prominent members of the KMT left, such as Liao Zhongkai, and men who would play instrumental roles in the future of China but during the Strike-Boycott were officials stationed at the famous Whampoa Academy, like Zhou Enlai and Chiang Kai-shek, to help secure financial support, weapons, and military training that transformed Hong Kong Chinese workers who found sanctuary in Canton into members of a paramilitary force that ruthlessly enforced the boycott of Hong Kong (Chan, 1975, pp. 318-319; Chan, 1994, pp. 46-47). Even more so than the labour actions of 1920 and 1922, the Canton regime during the StrikeBoycott was responsible for the hardening of resolve among members of the Hong Kong grassroots in their popular campaign to cripple British Hong Kong.

In the words of British Hong Kong authorities, during the height of the Strike-Boycott, "the great majority of household servants, sailors, engineers, and workers of all kinds had deserted their post" (Colonial Office, 1927a, p. 2). The Strike-Boycott imposed a boycott of British goods and placed an embargo on British shipping, actions that led to the economic hollowing out of Hong Kong, paralyzed the colony, and created widespread bankruptcies among its businesses. Rent rates declined by around 60 percent and the values of shares in the stock market plummeted by 40 percent (Chan, 1975, p. 329). Even the giant Hongkong and Shanghai Banking Corporation (HSBC), "the pillar of the colony's finance and the major instrument of British economic activities in China," saw the price of its shares dropped by 11.5 percent (Chan, 1975, p. 329). Governor Stubbs had to request an emergency $£ 3$ million loan from London "to relieve the colony's distress" (Chan, 1994, p. 45).

The Strike-Boycott entailed several layers of struggles. First, the Strike-Boycott was a revolt against British colonialism in Hong Kong and against British imperialism at large. Second, by enhancing the power and influence of the KMT left and the CCP, the StrikeBoycott triggered a KMT left-wing verse right-wing power struggle within Canton. Third, tensions between left-right and right-wing unions created by conflicting opinions on whether the CCP could be trusted, the duration of the Strike-boycott, and the degree to which a hostile stance against the British should be maintained that, at their worst, provoked intra-union strife among activists possessing contrasting political orientations within the same organization (Lau, 1990, pp. 210-211). A manifestation of this left-right division within the labour movement was the refusal of the Mechanics' Union to participate in the Strike-Boycott, as its conservative leadership was highly suspicious of the CCP (Chan, 1975, p. 313). A sense of unity that was created by Cantonese solidarity and Chinese nationalism and sustained by the United Front eventually succumbed to divergent political ideologies among participants of the Strike-Boycott and members of the grassroots in the colony and Canton.

Due to the need to concentrate all political, military and diplomatic resources to advance the KMT Northern Expedition into central and eastern China, the Strike-Boycott was terminated on the $15^{\text {th }}$ anniversary of the 1911 Revolution on 10 October 1926 (Colonial Office, 1927b, p. 1; Tsang, 2004, p. 100). While it didn't achieve the liquidation of British colonialism in Hong Kong, the Strike-Boycott did establish enough monument for the KMT to move forward and launch the Northern Expedition, thereby creating the foundation for the Nanjing regime (Chan, 1975, p. 47, p. 71, pp. 350-351). As part of the settlement, the British didn't object to the imposition of the 2.5 percent to 5 percent maritime customs surcharge levied by the 
Canton regime that paved the way for China regaining tariff independence in 1929 (Chan, 1975, p. 353). It also created a high tide of mass actions that spread to central and eastern China. Shanghai fell under the control of the KMT in March 1927, and the retrocession of Hankou and Jiujiang occurred in July 1927 (Chan, 1994, p. 52; Pantsov, 2000, p. 128; Jackson, 2017, p. 239). It is not an exaggeration to state that the actions of strikers in South China was of vital importance to the liberation of regions such as Hankou and the eventual success of the North Expedition, which was a rare occasion in Chinese history in which a political and military campaign to win national power was originated in Guangdong, or more precisely, the KMT's home base in Canton. Cantonese solidarity, of which Hong Kong Chinese were vital adherents, therefore contributed mightily to the KMT's successful completion of the Northern Expedition, the conclusion of which witnessed the party assuming control over significant portions of China (Chan, 2010, p. 5).

It should be noted that their immense contributions notwithstanding, none of the demands presented by the strikers regarding reforms in Hong Kong were met; indeed, indictive of the colonial regime's vindictiveness, the Seamen Union, which had bested the colonial administration in 1922 and was an important contributor to the Strike-Boycott, was outlawed in 1927 (Chan, 1994, p. 53). The Strike-Boycott nevertheless forced the colonial regime to become more sensitive to the local Chinese population by appointing the first Chinese to the Executive Council (Sir Shouson Chow) and to establish a school of Chinese studies at the University of Hong Kong (Carroll, 2005, p. 141, p. 155). An unexpected outcome of the Strike-Boycott, according to John Carroll, was the consolidation of a Hong Kong identity, at least among the colony's Chinese elites who had played "an active role in combating" the Strike-Boycott through actions such as counterpropaganda and the establishment of a "Labour Protection Bureau" to undermine the intimidation tactics of the strikers and whose families had, in stark contrast with members of the Chinese grassroots who simply saw the colony as their place of work, been in Hong Kong for generations. The colony's near extinction during the Strike-Boycott made "leading Chinese" such as Shouson Chow realize that their wealth and social status were dependent upon the preservation of Hong Kong's British status and the city's separation from the rest of China (Carroll, 2005, p. 34, p. 104, p. 132, pp. 134-135, p. 139, pp. 143-146, pp. 156-158).

An important legacy of the Strike-Boycott was that its conclusion triggered the final split between the KMT and the CCP that ended the United Front. It was in the aftermath of the April 1927 purge carried out by the KMT against its former CCP allies that the CCP staged the Canton Commune Uprising, essentially a full-scale urban putsch, in December 1927 (Lau, 1990, pp. 232-233, p. 245). As stated by Tsang (2004, p. 100), while the colony served as a safe haven and planning center for the leaders of the uprising, the workers of Hong Kong were not enthusiastic supporters of the CCP. Although there remained a substantial number of Hong Kong strikers lingering in Canton at this juncture, including some 300 Seamen's Union members, they played a very small role in this doomed insurrection (Zhou, 2009, p. 84). The major labour contingent that joined the insurrection was made up of 300 rickshaw pullers, most of them natives of Guangdong. CCP pioneer Peng Bai was an enthusiastic participant of the Uprising (Lau, 1999, p. 87, p. 90). The Uprising was "a major tragedy of the fledging Chinese Communist Movement", one that left Canton "visibly shaken" as "trade was seriously disrupted. . .and grave apprehension filled the air" (Lau, 1999, p. 95). Th refusal of Hong Kong Chinese workers to participate in the Canton Uprising demonstrates to historians their rational sense of patriotism. They were simply not willing to engage in a brutal vendetta for an extreme partisan campaign with a flawed strategy and uncertain objective. Patriotism has its limits, and patriotism is to the land, to the people, to the social-culture heritage, and to the glorious historical legacy that were higher and far beyond partisan claims and extremist pretensions.
GuangdongHong Kong nexus 
PAP

24,3

262

\section{Conclusion}

Hong Kong Chinese workers were vital contributors to some of China's most important collective actions. The political energy unleashed by the Canton-Hong Kong Strike-Boycott motivated Chinese in Shanghai, Hankou and Jiujiang to similarly revolt against foreign rule in 1927. A sense of Cantonese solidarity that was fundamental to mass actions in Canton and Hong Kong was therefore an overwhelmingly important component of Chinese national efforts against foreign occupations in the 1920s. If a sense of admiration for one's homeland was a necessary ingredient for successful popular movements, then it was Hong Kong Chinese's abiding allegiance to Canton that made them such dangerous opponents of their colonial masters. After all, for the majority of Hong Kong Chinese, Guangdong was their ancestral homeland, and Canton was their political Jerusalem that granted them a sanctuary during their hours of need. Through the examination of the triangular relations between Hong Kong, Canton, and China, a conclusion could be made that in $20^{\text {th }}$ century China, regional solidarity reinforced Chinese nationalism, as Cantonese participants of campaigns against colonialism were convinced that their rebellions against colonial rule would be joined by Chinese in other regions who were similarly oppressed by the imperial powers.

\section{References}

Carroll, J. (2005), Edge of Empires: Chinese Elites and British Colonials in Hong Kong, Harvard University Press, Cambridge.

Carroll, J. (2007), A Concise History of Hong Kong, Rowman \& Littlefield Publishers, Inc., Plymouth.

Chan, M.K. (1975), Labor and Empire: The Chinese Labor Movement in the Canton Delta, 1895-1927, $\mathrm{PhD}$ Thesis, Department of History, Stanford University, California.

Chan, M.K. (1994), "Hong Kong in Sino-British conflict: mass mobilization and the crisis of legitimacy, 1912-26”, in Chan, M.K. (Ed.), Precarious Balance: Hong Kong Between China and Britain, 18421992, M.E. Sharpe, New York, pp. 27-59.

Chan, M.K. (1996), "A turning point in the modern Chinese revolution: the historical significance of the Canton decade, 1917-27”, in Hershatter, G., Honig, E., Lipman, J.N. and Stross, G. (Eds.), Remapping China: Fissures in Historical Terrain, Stanford University Press, California, pp. 324-329.

Chan, M.K. (2010), "The historical role of Guangdong in the transformation of modern China in the early $20^{\text {th }}$ century", in Chan, M.K. and Rao, M.J. (Eds.), Modern History of the Lingnan Region: Guangdong and Guangdong-Hong Kong Relations, 1900-1938 (in Chinese), The Commercial Press, Hong Kong, pp. 1-31.

Colonial Office (1913), Colonial Reports - Annual. No. 762. Hong Kong. Report for 1912, Her Majesty's Stationary Office, London.

Colonial Office (1919), Colonial Reports - Annual. No. 1001. Hong Kong. Report for 1918, Her Majesty's Stationary Office, London.

Colonial Office (1920), Colonial Reports - Annual. No. 1071. Hong Kong. Report for 1919, Her Majesty's Stationary Office, London.

Colonial Office (1922), Colonial Reports - Annual. No. 1139. Hong Kong. Report for 1921, Her Majesty's Stationary Office, London.

Colonial Office (1927a), Colonial Reports - Annual. No. 1324. Hong Kong. Report for 1925, Her Majesty's Stationary Office, London.

Colonial Office (1927b), Colonial Reports - Annual. No. 1356. Hong Kong. Report for 1926, Her Majesty's Stationary Office, London.

Des Voeux, G.W. (1889), Report on the Condition and Prospects of Hong Kong and on Recent Events in the Colony, Noronha \& Co, Hong Kong. 
Jackson, I. (2017), Shaping Modern Shanghai: Colonialism in China's Global City, Cambridge University Press, New York.

Jacobs, D. (1981), Borodin: Stalin's Man in China, Harvard University Press, Cambridge.

Lau, K.C.C. (1990), China, Britain and Hong Kong, 1895-1945, The Chinese University Press, Hong Kong.

Lau, K.C.C. (1999), From Nothing to Nothing: The Chinese Communist Movement and Hong Kong, 1921-1936, Hong Kong University Press, Hong Kong.

GuangdongHong Kong nexus

Morris, J. (1988), Hong Kong, Viking, Hong Kong.

Munn, C. (2009), Anglo-China: Chinese People and British Rule in Hong Kong, 1841-1880, 2nd ed., Hong Kong University Press, Hong Kong.

Nield, R. (2015), China's Foreign Places: The Foreign Presence in China in the Treaty Port Era, 18401943, Hong Kong University Press, Hong Kong.

Pantsov, A. (2000), The Bolsheviks and the Chinese Revolution 1919-1927, Routledge, London and New York.

Siu, H. (1996), "Remade in Hong Kong: weaving into the Chinese cultural tapestry", in Liu, T.T and Faure, D. (Eds.), Unity and Diversity: Local Cultures and Identities in China, Hong Kong University Press, Hong Kong, pp. 177-197.

Siu, H. (2016), Tracing China: A Forty-Year Ethnographic Journey, Hong Kong University Press, Hong Kong.

Smith, A.D. (1993), "The ethnic sources of nationalism”, Survival: Global Politics and Strategy, Vol. 35 No. 1, pp. 48-62.

Smith, A.D. (1998), Nationalism and Modernism: A Critical Survey of Recent Theories of Nations and Nationalism, Routledge, New York.

Tsai, J.F. (1993), Hong Kong in Chinese History: Community and Social Unrest in the British Colony, 1842-1913, Columbia University Press, New York.

Tilly, C. (1978), From Mobilization to Revolution, Random House, New York.

Tsang, S. (Ed.) (1995), A Documentary History of Hong Kong - Government and Politics, Hong Kong University Press, Hong Kong.

Tsang, S. (2004), A Modern History of Hong Kong, I.B. Tauris, London.

Wakeman, Jr., F. (1966), Strangers at the Gate: Social Disorder in South China, 1839-1861, University of California Press, Berkley and Los Anglos.

Wong, J.Y. (1998), Deadly Dreams: Opium and the Arrow War (1856-1860) in China, Cambridge University Press, London.

Zhou, Y. (2009), History of Hong Kong's Labour Movement (in Chinese), Li Xun Publishing, Hong Kong.

\section{About the author}

Kent Wan is a lecturer at Nanjing University and is the first Canadian to hold a teaching position at its School of History. Kent's bilingual (Mandarin and English) history seminar, China and the World, 17931949, has been well-received by the School's graduate students. Educated in Canada and Australia, Kent has received academic awards from the National Library of Australia and the Chinese Academy of Social Sciences. Being a young scholar with a growing research record, his articles and book reviews focusing on China's past have appeared in outlets such as Humanities, Arts and Society and Chinese Studies. Kent Wan can be contacted at: wanpakkin@hotmail.com

For instructions on how to order reprints of this article, please visit our website:

www.emeraldgrouppublishing.com/licensing/reprints.htm

Or contact us for further details: permissions@emeraldinsight.com 